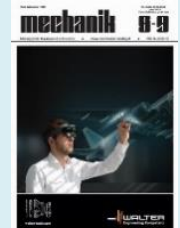

Authors: Edward Miko, Łukasz Nowakowski, Michał Skrzyniarz

Title of article: „, Wpływ wybranych warunków skrawania na siłę i moment podczas wiercenia żeliwa szarego” (, Influence of selected cutting conditions on torque and cutting force during drilling of gray cast iron")

Mechanik, Vol. 91, No. 8-9 (2018): pages 760-762

DOI: https://doi.org/10.17814/mechanik.2018.8-9.126

\title{
Influence of selected cutting conditions on torque and cutting force during drilling of gray cast iron
}

\author{
Wpływ wybranych warunków skrawania na siłę i moment \\ podczas wiercenia żeliwa szarego
}

\author{
EDWARD MIKO \\ ŁUKASZ NOWAKOWSKI \\ MICHAL SKRZYNIARZ *
}

The impact of selected cutting parameters (cutting speed and cutting feed) on the torque and cutting force during drilling gray cast iron EN-GJL-250 was analyzed. The drilling operation was carried out by Allied Machnie drill series: DEM22000S-20FM, on the Hermle B300 vertical milling center. The measurement of the torque and the cutting forces during drilling was carried out by Kistler device.

KEYWORDS: torque and cutting force, drilling, insert drill, grey cast iron

Drilling is the most efficient method of shaping holes in comparison with, for example, milling and turning. The holes are made with monolithic drills or assemblies. During the process, the forces and cutting moment are observed on the workpiece and directly on the tool, and as a result - on the machine spindle. There is a limit diameter for a given drill geometry due to the machine spindle load and due to the strength properties of the material of the workpiece, where it is possible to make a hole in the full material. To reduce the load on the spindle, holes with smaller diameters are most often made, and then a hole with a larger diameter is created in the drilling operation [1].

In addition, the method of fixing the material must be taken into account. When using three-point or six-jaw selfcentering chucks, there is a risk of rotating or pushing the workpiece in the mounting bracket. Due to this, during drilling tests, there is a need to monitor the force and the moment of cutting.

The value of the moment and cutting force is influenced by: cutting parameters (i.e. cutting speed, feed rate), as well as drill geometry, wear and properties of the material being processed [2, 3]. Consumption depends on the amount of heat generated in the cutting process as a correlation between friction factors and cutting force [4].

To reduce the temperature in the cutting zone, cooling and lubricating liquids are used [5]. They are supposed to remove chips from chip flutes, eliminate the formation of rotor on the tool's edge, reduce coefficient of friction and remove heat from the cutting zone [6].

\footnotetext{
* Dr hab. inż. Edward Miko (emiko@tu.kielce.pl), dr inż. Łukasz Nowakowski (lukasn@tu.kielce.pl), mgr inż. Michał Skrzyniarz (mskrzyniarz@tu.kielce.pl) - Katedra Technologii Mechanicznej i Metrologii Politechniki Świętokrzyskiej
}

An additional phenomenon occurring during the making of through-openings is the emergence of a deflection [7].

All these factors affect process productivity, tool life, dimensional and dimensional accuracy [8, 9] and parameters of the geometric structure of the objects produced $[10,11]$.

\section{Research methodology}

The purpose of the research was to determine the influence of cutting parameters - i.e. cutting speed $v_{\mathrm{c}}$ and feed $f_{\mathrm{n}}$ - at the cutting moment $M_{\mathrm{c}}$ and the feed force $F_{\mathrm{f}}$. In addition, the characteristics of the torque and shear force for drilling the hole were compared:

- without feeding a cooling liquid,

- using a liquid applied in a flooded manner,

- with cooling by a tool under 40 bar pressure.

The values of the machining parameters were selected on the basis of the manufacturer's recommendations and additionally extended. The range of the feed rate was selected in the range from 0.15 to $0.25 \mathrm{~mm} / \mathrm{rev}$ at 0.01 $\mathrm{mm} / \mathrm{rev}$. The cutting speed varied from 60 to $110 \mathrm{~m} / \mathrm{min}$ with a step of $5 \mathrm{~m} / \mathrm{min}$. The tests were carried out on the Hermle B300 vertical milling center.

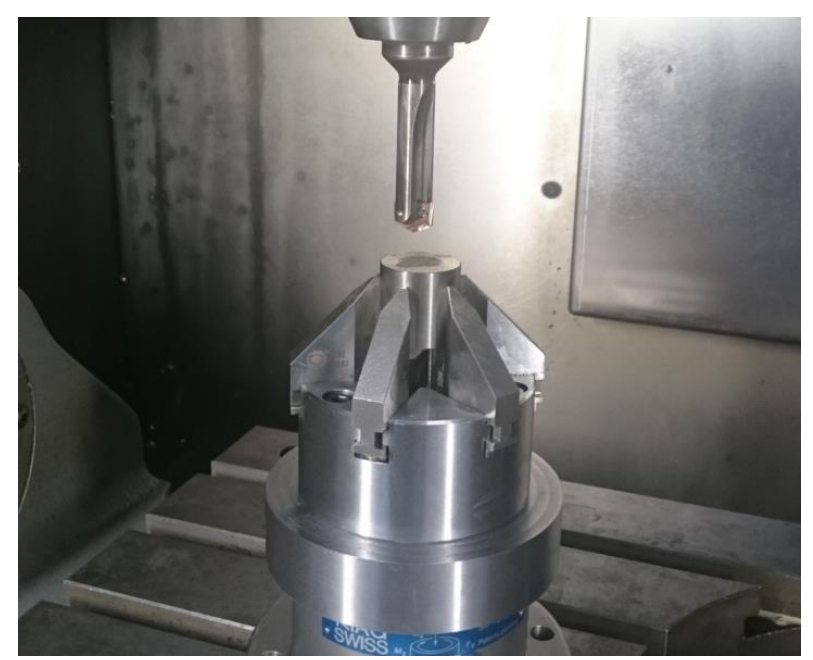

Fig. 1. Stand for measuring the moment and cutting force during drilling 
Drilling was carried out with a folding drill Allied Machnie DEM22000S-20FM, equipped with a $450 \mathrm{H}-14$ plate with a diameter of $14 \mathrm{~mm}$, with an angle $\lambda_{\mathrm{S}}=0^{\circ}$. The $138^{\circ}$ tip angle plate was made of HSS material, covered with the company's Super Cobalt AM200 coating. The cutting torque and feed force were examined using the Kistler 8152A1 drilling dynamometer.

Fig. 1 presents the research stand used during the experiment. The maximum values of cutting moment and force were determined for all tests. The workpiece was a sample in the shape of a cylinder with a diameter of $23 \mathrm{~mm}$ and a height of $25 \mathrm{~mm}$, made of cast iron EN-GJL-250 ( Rm $=250 \div 350 \mathrm{MPa}, 180 \div 220 \mathrm{HB}$ ) with graphite in the flake form.

\section{Test results}

Fig. 2 shows the influence of feed per revolution on the maximum feed force. The graph shows that the cutting force increases with the feed value. This is due to the increase in the cross section of the chip, which is shaped during one revolution of the cutting tool, and to the increase in the length at which the drill interacts in a plastic manner for the material during one revolution.

The minimum value of the feed force was noted for the $f_{n}$ $=0.15 \mathrm{~mm} / \mathrm{rev}$ force and it was $F_{\mathrm{f}}=1355 \mathrm{~N}$, whereas for the feed $f_{\mathrm{n}}=0.25 \mathrm{~mm} / \mathrm{rev}$ the force value almost doubled: $F_{\mathrm{f}}=$ $2862 \mathrm{~N}$. Speed cutting was fixed at a constant level of $v_{\mathrm{c}}=$ $85 \mathrm{~m} / \mathrm{min}$.

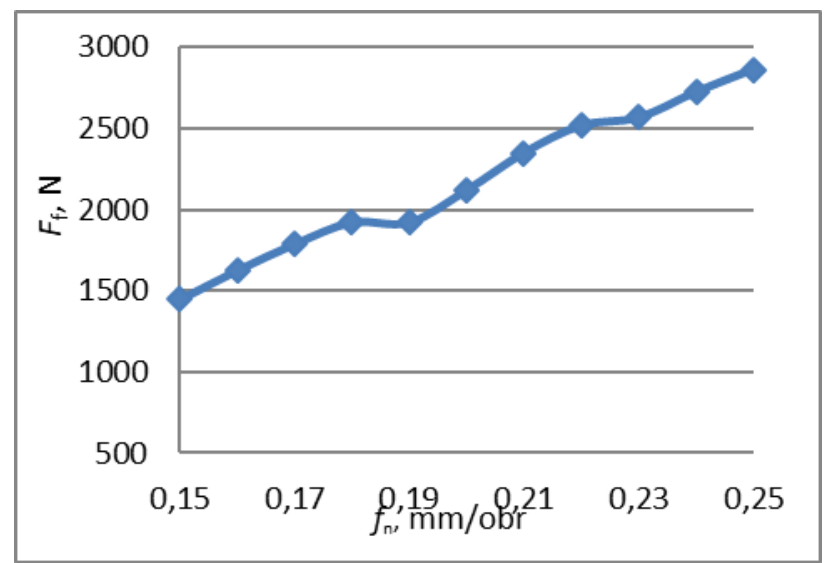

Fig. 2. Value of the feed force $F_{\mathrm{f}}$ in the feed function per revolution $f_{\mathrm{n}}$ for the cutting speed $v_{\mathrm{c}}=85 \mathrm{~m} / \mathrm{min}$

Fig. 3 shows the influence of the cutting moment in the feed per revolution function. In this case, there is also an upward trend in the cutting moment as the feed increases. In some cases, the value of the cutting torque decreased with increasing feed. This may be due to the heterogeneous structure of the material. The smallest value of the moment, $M_{\mathrm{c}}=7.4 \mathrm{Nm}$, was recorded for the sample made with the $f_{\mathrm{n}}$ $=0.15 \mathrm{~mm} / \mathrm{rev}$, while the highest value of $M_{\mathrm{c}}=13 \mathrm{Nm}$ was obtained for $f_{\mathrm{n}}=0.24 \mathrm{~mm} / \mathrm{rev}$.

Fig. 4 shows the influence of cutting speed on the value of feed force during drilling. The graph shows that the feed force tends to decrease as the cutting speed increases, which results from the increased process dynamics. The cutting tests were carried out with a constant feed $f_{n}=0.2$ $\mathrm{mm} / \mathrm{rev}$. The highest value was recorded for $v_{\mathrm{c}}=60 \mathrm{~m} / \mathrm{min}$ and it was $F_{\mathrm{f}}=2348 \mathrm{~N}$, while the smallest value, $F_{\mathrm{f}}=1824$ $\mathrm{N}$, was recorded for $v_{\mathrm{c}}=105 \mathrm{~m} / \mathrm{min}$.

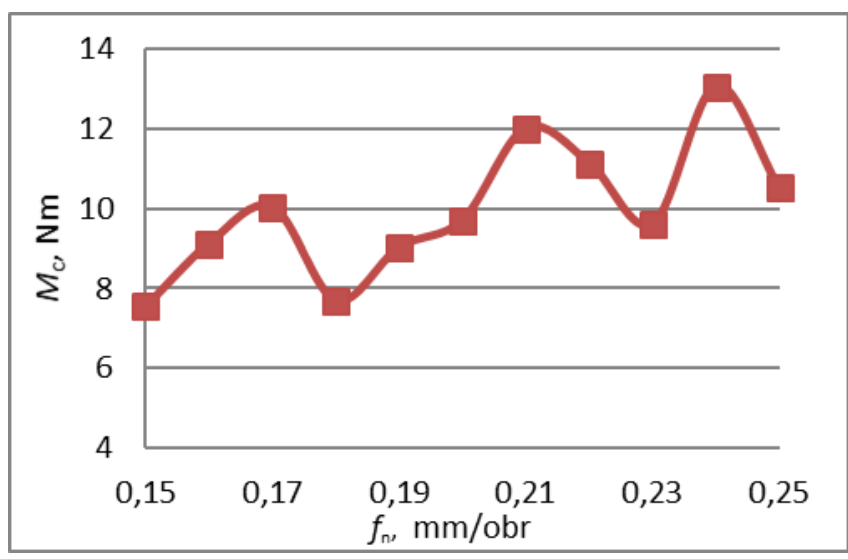

Fig. 3. Cutting moment value $M_{\mathrm{c}}$ in feed function per revolution $f_{\mathrm{n}}$ for cutting speed $v_{\mathrm{c}}=85 \mathrm{~m} / \mathrm{min}$

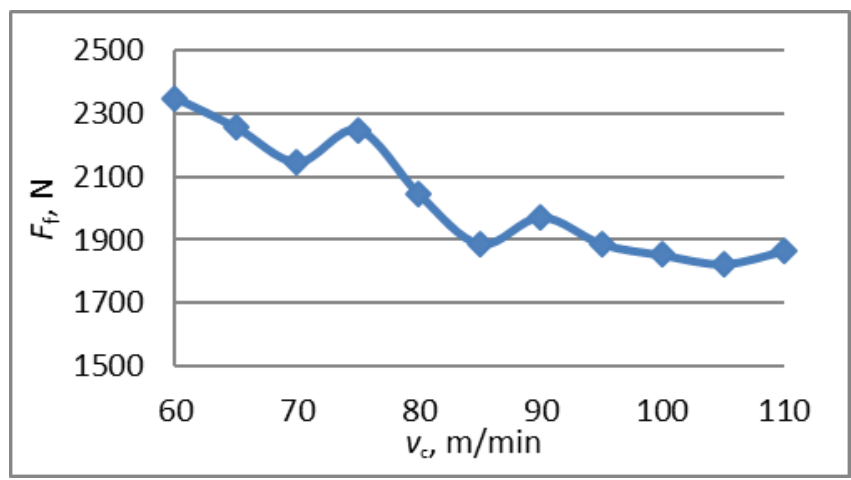

Fig. 4. Value of the feed force $F_{f}$ as a function of the cutting speed $v_{\mathrm{c}}$ for the feed per revolution $f_{\mathrm{n}}=0.2 \mathrm{~mm} / \mathrm{rev}$

Fig. 5 shows the influence of cutting speed on the cutting torque values. There was no noticeable trend defining this impact. In the entire tested range the torque value varies from 9 to $11.5 \mathrm{Nm}$.

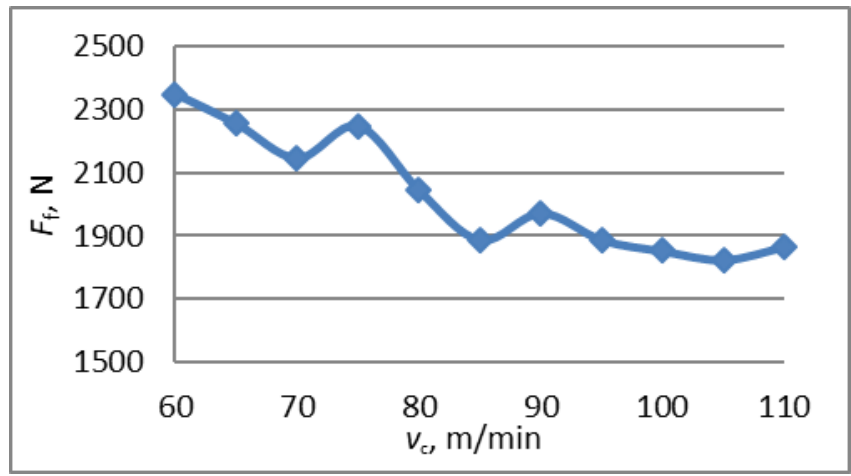

Fig. 5. Cutting torque value $M_{\mathrm{c}}$ in the cutting speed function $v_{\mathrm{c}}$ for feed per revolution $f_{n}=0.2 \mathrm{~mm} / \mathrm{rev}$

In addition to the influence of cutting parameters, i.e. speed and feed, on the moment and cutting force, the influence of the methods of feeding the cooling and lubricating liquid was examined. In the first case, a cutting test was carried out without liquid feeding. Drilling was then carried out with liquid delivery in a flooded manner. The third attempt consisted in supplying a cooling-lubricating liquid through channels made in the tool body. The pressure value provided by the supply system is 40 bar.

Fig. 6 shows how the coolant-co-lubricant liquid or its lack affects the feed force during drilling. All tests were carried out with the same cutting parameters, i.e.: $v_{c}=85$ $\mathrm{m} / \mathrm{min}, f_{\mathrm{n}}=0.15 \mathrm{~mm} / \mathrm{rev}$. In the first case, i.e. during processing without liquid feed (blue color), the highest feed force values were noted. The largest value is $F_{\mathrm{f}}=1355 \mathrm{~N}$. 
In the second processing option, i.e. using the liquid applied in a flooding manner (red color), the value of the feed force is significantly lower. Its maximum values were noted at the beginning and end of the drilling process. In the remaining part, the value of the force stabilizes. The maximum recorded value is $F_{f}=988 \mathrm{~N}$, which is $73 \%$ of the force value in the case of machining without the application of a cooling liquid.

In the last analyzed variant - with the application of liquid through the body of the tool (green color) - the smallest value of force $F_{f}=888 \mathrm{~N}$ was noted. No noticeable sharp jumps in the cutting force were noted at the beginning and end of the drilling process. During drilling, the strength shows an upward trend.

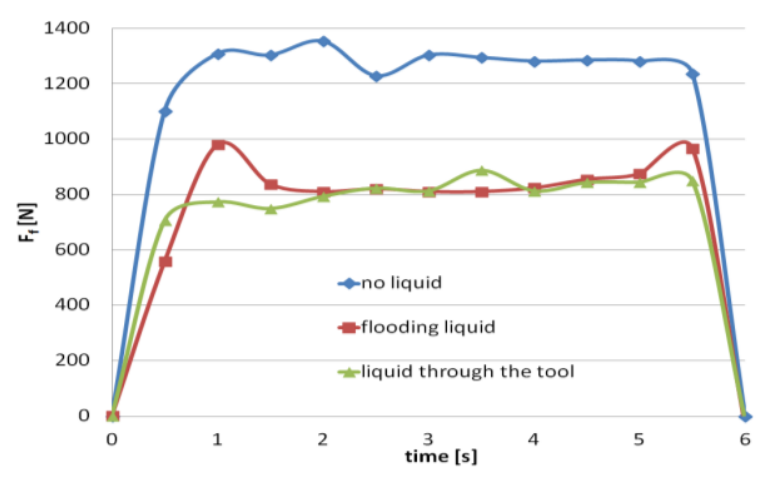

Fig. 6. Effect of cooling on the course of feed force for $v_{c}=85$ $\mathrm{m} / \mathrm{min}, f_{\mathrm{n}}=0.15 \mathrm{~mm} / \mathrm{rev}$

During all tests, three basic stages of forming the hole are visible. The first in which force and moment grow, which is responsible for starting the drilling process until reaching the depth at which the drill works with the entire diameter. The second stage, stabilized torque and cutting force, which results from the stabilized work of the drill blades. The third stage, in which the moment of the moment and the cutting force is noticeable, connected with the end of the drilling process and the exit of the drill from the hole.

In addition to the force value, the cutting moment was measured in parallel (fig. 7).

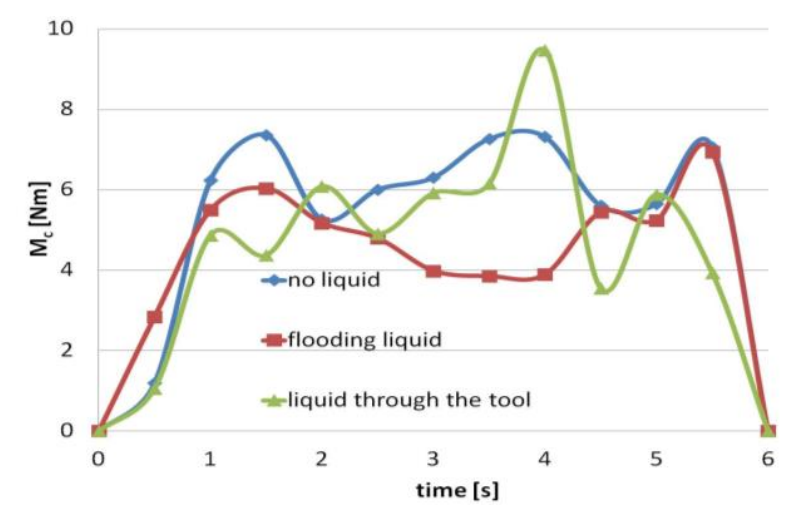

Fig. 7. Effect of the cooling type on the maximum cutting moment for: $v_{\mathrm{c}}=85 \mathrm{~m} / \mathrm{min}, f_{\mathrm{n}}=0.15 \mathrm{~mm} / \mathrm{rev}$

The lowest value of the moment during the drilling process with full engagement of the cutting edge was noted for the variant without the use of machining liquids. The highest values of torque were noted at the start and end of the hole formation. When the liquid is fed in a dependent manner, the moment has the greatest value in the first phase of forming the hole. At the final stage of drilling, the cutting torque is almost identical to that for drilling without the application of a cutting fluid. This phenomenon is caused by the fact that at this depth liquid access to the cutting zone is hindered, which makes drilling conditions similar.

When the tool is cooling by the tool, the moment is lowest in the initial machining phase. Then it grows and in the fourth second it reaches its highest value. This may be due to chips getting between the wall of the shaped hole and the body of the tool.

\section{Conclusions}

On the basis of the results of the momentum and cutting force tests for the single described case of EN-GJL-250 iron drilling, the following conclusions were made:

- cutting moment and feed force during drilling show an upward trend as the feed per revolution increases. This phenomenon is caused by the increase of the cross-section of the chip and the increase of the section in which the drill interacts plastically with the material to be processed,

- increase in the cutting speed causes a decrease in the feed force,

- feeding of the cutting fluid affects the cutting force; the smallest value was noted when feeding the cutting fluid through the tool body; in the case of flooding of liquids, the maximum cutting moment is $73 \%$ of the feed force for processing without cooling,

- when forming the hole above $1.5 \mathrm{D}$ no significant difference was noted at the time of cutting with and without cooling; this is due to the difficult access of liquids to the cutting zone,

- when cutting the machining fluid through the tool body, lower cutting torques were recorded at the beginning and end of the cutting process; in this course there is a characteristic point of increase in the cutting moment, which may correspond to the ingress of chips between the wall of the formed hole and the body of the tool.

\section{REFERENCES}

1. Jaworski J., Kluz R. „Badanie wpływu zużycia wierteł ze stali HS 2-5-1 na siłę poosiową i moment skrawania przy wierceniu stali konstrukcyjnej". Mechanik. 8-9, CD2 (2014): pp. 127-134.

2. Sreenivasulu R., Rao Ch. "Effect of drilling parameters on thrust force and torque during drilling of aluminium 6061 alloy - based on Taguchi design of experiment". Journal of Mechanical Engineering. 46 (2017): pp. 41-48.

3. Cieciak S., Karbowski K. „Nadzorowanie procesu wiercenia głębokich otworów”. Inżynieria Maszyn. 15, 3 (2015): pp. 213221.

4. Naseer A. "Effect of changing drilling parameters on thrust force and torque". Middle-East Journal of Scientific Research. 21, 2 (2014): pp. 347-352.

5. Kulkarni A., Murgod V., Kittur J. "Minimum quantity lubrication in deep hole drilling". International Journal of Research in Engineering and Technology. 3, 3 (2014): pp. 712-716.

6. Zalewski K., Pałka T. „Wpływ minimalnego smarowania na moment skrawania i chropowatość powierzchni $\mathrm{w}$ procesie wiercenia stopu aluminium". Mechanik. 8-9, CD2 (2015): pp. 213-221.

7. Bartoszuk M., Piróg A. „Wybrane zagadnienia minimalizacji wypływki pojawiającej się przy wierceniu otworów przelotowych". Mechanik. nr 8-9, CD2 (2015): pp. 374-380.

8. Adamczak S. "Pomiary geometryczne powierzchni. Zarysy kształtu, falistość i chropowatość ". Warszawa: WNT, 2008.

9. Nowakowski Ł., Miko E., Skrzyniarz M. „Ocena dokładności wymiarowo-kształtowej otworów wierconych wiertłami składanymi". Mechanik. 8-9 (2016): pp. 1200-1201.

10. Miko E., Skrzyniarz M. „Porównanie cech chropowatości żeliw po obróbce tokarskiej". Mechanik. 8-9, CD (2015): pp. 724732.

11. Adamczak S., Świderski J., Dobrowolski T. „Wpływ wykorzystania funkcji łączenia pomiarów na parametry stereometrii powierzchni". Mechanik. 2 (2018): pp. 118-120. 
Translation of scientific articles, their computer composition and publishing them on the website www.mechanik.media.pl by original articles in Polish is a task financed from the funds of the Ministry of Science and Higher Education designated for dissemination of science.

Ministry of Science and Higher Education

Republic of Poland 